\title{
PENGUATAN LITERASI DIGITAL GENERASI MUDA MUSLIM DALAM KERANGKA KONSEP ULUL ALBAB
}

\author{
Tian Wahyudi \\ Universitas Islam Indonesia \\ Jl. Kaliurang, Daerah Istemewa Yogyakarta \\ tianwahyudi@uii.ac.id
}

DOI: $10.46781 /$ al-mutharahah.v18i2.368

\begin{abstract}
This article examines how to strengthen digital literacy referring to the ulul albab concept. Through a study of various literatures relevant to the topic of discussion, this article aims to examine the main components of ulul albab and make it a framework for strengthening digital literacy for the younger generation of Muslims. These components are dhikr, thought and amal shaleh. Through these three components, the young Muslim generation is able to optimize digital media as a means of self-development and can contribute to the benefit of the ummah and society in general. Increasing dzikrullah essentially is building and increasing awareness of a Muslim about his life's vision and mission that the life of the world should be a provision for the goodness of the Hereafter. In various circumstances and activities, he is always aware that every action he does, no matter how small, has consequences for his future life. Likewise, when using digital media, he will optimize digital means for good and avoid various bad attitudes and behaviors, which are contrary to shariah. Meanwhile, for the strengthening of the thinking aspect, namely by strengthening and improving critical thinking skills and making digital media a means of increasing knowledge and skills. As for righteous deeds, in fact, it cannot be separated from the aspect of dhikr and thought. The better the quality of dhikr and thought, then this will encourage the quality of his deeds as well. Digital media can be a means of doing various good based on sharia, namely by: (1) spreading useful knowledge; (2) amarmakruf nahi munkar; (3) producing various positive-educative and Islamic digital media or content; (4) strengthening silaturrahim and ukhuwwah Islamiyyah; and (5) maintaining morals in social media.
\end{abstract}

Keywords: Digital Literacy, Young Generation, and Ulul Albab

\begin{abstract}
Abstrak
Artikel ini mengkaji bagaimana penguatan literasi digital mengacu kepada konsep Ulul Albab. Melalui pengkajian terhadap berbagai literatur yang relevan dengan topik pembahasan, artikel ini bertujuan untuk mengkaji komponen-komponen utama ulul albab dan menjadikannya sebagai kerangka bagi penguatan literasi digital generasi muda muslim. Komponen-komponen tersebut yaitu dzikir, pikir, dan amal shaleh. Melalui penguatan pada tiga komponen tersebut generasi muda muslim mampu mengoptimalkan media digital sebagai sarana pengembangan diri dan dapat berkontribusi bagi kemaslahatan umat dan masyarakat secara umum. Meningkatkan dzikrullah hakikatnya adalah membangun dan meningkatkan kesadaran seorang muslim akan visi dan misi hidupnya bahwa kehidupan dunia harusnya menjadi bekal untuk mendapatkan kebaikan Akhirat. Dalam berbagai keadaan dan aktivitas, dia selalu sadar bahwa segala perbuatan yang dilakukan-sekecil apapun memiliki konsekwensi bagi kehidupannya di masa depan. Demikian pula saat bermedia digital, dia akan mengoptimalkan sarana digital untuk kebaikan dan menghindari berbagai sikap dan prilaku yang buruk, yang bertentangan dengan syariat Islam. Sementara untuk penguatan dari aspek pikir yaitu dengan menguatkan dan meningkatkan kemampuan berpikir kritis dan menjadikan media digital
\end{abstract}


sebagai sarana peningkatan wawasan dan keterampilan. Adapun amal shaleh, sejatinya tidak terlepas dari aspek dzikir dan pikir. Semakin baik kualitas dzikir dan pikirnya, maka hal tersebut akan mendorong kepada kualitas amalnya juga. Media digital dapat menjadi sarana dalam melakukan berbagai kebaikan yang berlandaskan syariat yaitu dengan: (1) menebarkan ilmu yang bermanfaat; (2) menyeru kepada kebaikan dan mencegah kemunkaran; (3) memprodukasi berbagai media atau konten digital yang positif-edukatif dan Islami; (4) menguatkan silaturrahim dan ukhuwwah Islamiyyah, serta (5) menjaga akhlak dalam bermedia sosial.

Kata Kunci: Literasi Digital, Generasi Muda dan Ulul Albab

\section{A. Pendahuluan}

Generasi muda sebagai bagian dari masyarakat yang saat ini paling dekat dengan dunia digital (digital native) dituntut untuk mampu menggunakan teknologi digital dengan baik dan bijak. Kemudahan akses informasi yang merupakan konsekuensi dari pesatnya perkembangan teknologi digital menuntut kemampuan generasi muda dalam memilih, memilah, dan menyebarkan informasi. Hal ini karena internet sebagai jejaring informasi dan komunikasi dalam dunia digital digunakan oleh beragam latar belakang pengguna dengan beragam tujuan dan kepentingan. Oleh karenanya, muatan informasi yang ada di dalamnya, selain memiliki dampak positif yang sejalan dengan nilai-nilai Islam, namun juga terdapat muatan negatif yang tidak sesuai dengan ajaran Islam.

Dalam kaitan di atas, perhatian terhadap generasi muda dalam hal literasi digital menjadi semakin relevan. Hal ini diperkuat juga dengan semakin bertambahnya masyarakat Indonesia yang melek digital. Survey yang dilakukan oleh Asosiasi Penyelenggara Jasa Internet Indonesia (APJII) untuk tahun 2019-2020 (Q2) menunjukan bahwa terdapat sebanyak 73,7 persen pengguna internet (196,7 juta pengguna) dari total populasi penduduk Indonesia. Jumlah tersebut mengalami penambahan dari tahun sebelumnya, yang berjumlah 64,8 persen. ${ }^{1}$ Berkaitan dengan waktu akses perhari, laporan Bank Dunia 2021 menunjukan bahwa rata-rata orang Indonesia berinternet sekitar enam jam per hari dan kelompok usia yang paling banyak menghabiskan waktu berinternet yakni usia 16 sampai 25 tahun, yaitu 9,7 jam per hari. ${ }^{2}$ Meningkatanya akses masyarakat terhadap jejaring internet menunjukan semakin mudahnya masyarakat dalam menggunakan media digital. Karenanya, pesatnya perkembangan teknologi digital bila ingin berdampak postif, maka harus ditopang dengan penguatan kemampuan literasi yang memadai. Dengan kata lain, membangun kesadaran untuk meningkatkan kemampuan literasi digital bagi setiap individu menjadi sangat penting, terutama lagi bagi generasi muda yang paling banyak memanfaatkan media digital dan menjadi generasi penerus bangsa dan umat sekaligus.

Berdasarkan latar belakang di atas, penulis dalam tulisan ini mencoba membangun model kerangka literasi digital berdasarkan pada konsep ulul albab. Kerangka tersebut dibangun dengan mengkontekstualisasikan konsep ulul albab dengan melakukan penguatan pada aspekaspek utama ulul albab yang relevan bagi penguatan literasi digital generasi muda muslim. Term ulul albab sendiri seringkali dikaitkan dengan pribadi atau sekelompok manusia yang memiliki keistimewa-keistimewaan. Sosok ulul albab dianggap istimewa sebab dia mempunyai kedalaman spiritualitas ( $d z i k r)$, ketajaman analisis ( $f i k r)$ dan memiliki kreatifitas atau aktifitas positif (amal shaleh). ${ }^{3}$ Tiga komponen utama yaitu $d z i k r$, fikr dan amal shaleh tersebut berpadu

${ }^{1}$ Asosiasi Penyelenggara Jasa Internet Indonesia, “Laporan Survei Internet APJII 2019 - 2020 (Q2),” Asosiasi Penyelenggara Jasa Internet Indonesia, vol. 2020, 2020, https://apjii.or.id/survei.

2 Monavia Ayu Rizaty, "Masyarakat RI Paling Banyak Gunakan Internet Untuk Berkomunikasi," 2021, https://databoks.katadata.co.id/datapublish/2021/07/29/masyarakat-ri-paling-banyak-gunakaninternet-untuk-berkomunikasi.

3 Abdul Basid, "Ulul Albab Sebagai Sosok Dan Karakter Saintis Yang Paripurna," in PROSIDING : Seminar Nasional Fisika Dan Pendidikan Fisika, vol. Vol 1, No, 2012, 281-91. 
dan saling berkaitan dalam sosok ulul albab. Dengan menguatkan generasi muda dalam tiga komponen inilah, diharapkan akan mampu menjawab berbagai tantangan era digital saat ini.

\section{B. Metode Penelitian}

Penelitian ini mengunakan penelitian kepustakaan yaitu mencari sumber penelitian dengan cara mengumpulkan dari beberapa literatur yang bersumber dari jurnal, buku dan sumber-sumber lainnya, agar lebih mudah dalam melakukan penelitian mengenai literasi digital generasi muda muslim.

\section{Pembahasan}

\section{Definisi dan Aspek Literasi Digital}

Bila merujuk berbagai pendapat para ahli terkait term literacy digital, ditemukan pendapat yang beragam. Paul Gilster mendefinisikan literasi digital dengan kemampuan dalam memahami dan menggunakan informasi dalam beragam format dari berbagai sumber yang disajikan melalui komputer, khususnya melalui media internet. Kemampuan tersebut meliputi kemampuan operasional atau yang bersifat teknikal dan penguasaan ide. ${ }^{4}$ Sementara itu, Acep Syaripudin dkk mengungkapkan bahwa, "literasi digital ialah kemampuan dalam penggunaan teknologi informasi dan komunikasi, untuk menemukan, mengevaluasi, memanfaatkan, membuat, dan mengkomunikasikan konten/informasi, dengan kecakapan kognitif maupun teknikal." 5 Pendapat lain dikemukakan oleh martin yang mengungkapkan bahwa, "literasi digital merupakan kesadaran, sikap, dan kemampuan individu dalam menggunakan alat dan fasilitas digital secara tepat untuk mengidentifikasi, mengakses, mengelola, mengintegrasikan, mengevaluasi, menganalisis, dan mensintesis sumber daya digital, membangun pengetahuan baru, membuat ekspresi media, dan berkomunikasi dengan orang lain, dalam konteks situasi kehidupan tertentu, untuk memungkinkan tindakan sosial yang konstruktif" 6

Dari tiga pendapat di atas, jika dicermati, maka masing-masing pengertian memiliki keluasan cakupan kemampuan yang berbeda. Namun demikian, dari ketiganya menunjukan ada dua aspek yang disepakati, yaitu aspek kognitif dan teknikal-operasional. Sementara itu, pendapat terakhir menambahkan aspek emosional dalam kemampuan literasi digital. Dengan demikian, seorang individu dapat dianggap memiliki kecakapan dalam hal literasi digital bila menguasai minimal aspek kognitif dan teknikal, dan bila merujuk kepada pendapat ketiga ditambah aspek emosional atau afektif yang ditunjukan dengan kata "kesadaran dan sikap".

Wan Ng menjelaskan lebih rinci terkait tiga aspek atau dimensi kemampuan dalam literasi digital. Menurutnya, dimensi kognitif berkaitan dengan kemampuan berpikir kritis dalam mencari, mengevaluasi, dan menciptakan siklus dalam menangani informasi digital. Menurut wan dimensi digital tersebut mengharuskan individu memahami masalah etika, moral dan hukum yang terkait dengan perdagangan online dan reproduksi konten yang menggunakan sumberdaya berbasis digital. Sementara dimensi teknikal berkaitan dengan kemampuan atau keterampilan dalam mengoperasikan Teknologi Informasi dan Komunikasi (TIK) dengan baik dalam kegiatan sehari-hari maupun dalam kegiatan pembelajaran. Adapun dimensi emosionalsosial yaitu berkaitan dengan kemampuan menggunakan media digital dengan penuh tanggung jawab dalam berkomunikasi, bersosialisasi, dan kegiatan belajar dengan (1) memperhatikan netiket melalui penerapan aturan, misalnya saat tatap muka daring, individu perlu menghormati dan menggunakan bahasa dan kata-kata yang tepat untuk menghindari kesalahpahaman; (2)

${ }^{4}$ Colin Lankshear and Michele Knobel, "Digital Literacy and Digital Literacies: Policy, Pedagogy and Research Considerations for Education," Nordic Journal of Digital Literacy 2015, no. 4 (2015): 9, https://doi.org/10.18261/issn1891-943x-2015-jubileumsnummer-02.

${ }^{5}$ Acep Syaripudin et al., Kerangka Literasi Digital Indonesia (www.literasidigital.id, n.d.), 4.

${ }^{6}$ Wan Ng, "Can We Teach Digital Natives Digital Literacy?," Computers and Education 59, no. 3 (2012): 1067, https://doi.org/10.1016/j.compedu.2012.04.016. 
melindungi keamanan dan privasi individu dengan menjaga informasi pribadi serahasia mungkin, kecuali sebatas yang dibutuhkan; (3) mampu mengenali sebuah ancaman dan cara menghadapinya dengan baik. ${ }^{7}$

\section{Konsep Ulul Albab: definisi, ciri-ciri dan komponen}

Secara etimologi kata Ulul Albab diambil dari bahasa Arab dan terdiri dari dua kata yakni "ulu" dan "albab". Kata, "ulu" berarti, "memiliki" (kelebihan/keistimewaan), dan kata, "albab" merupakan bentuk jamak dari kata "lubb" yang berarti inti, sari, bagian terbaik atau terpenting. 8 Al-Raghib al-Asfahani mengartikan "lubb" dengan "akal yang murni yang terbebas dari cela atau cacat." Sementara menurut Quraish Shihab kata "lubb" diumpamakan seperti kacang yang memiliki kulit yang menutupi isinya. Isinya tersebutlah yang dinamakan $l u b b .^{10}$

Quraish Shihab lebih lanjut menuturkan bahwa ulil albab adalah orang-orang yang memiliki akal yang murni yang tidak diselubungi oleh kabut "kulit", yakni kabut ide yang dapat melahirkan kerancuan berpikir. Seorang ulil albab mendapatkan bukti yang sangat nyata akan keesaan dan kekuasaan Allah swt melalui perenungan terhadap fenomena alam raya. ${ }^{11}$ Disamping itu, ia juga terus-menerus mengingat Allah, dengan ucapan, dan atau hati dalam seluruh keadaan, baik ketika bekerja atau istirahat, dalam posisi berdiri atau duduk atau saat berbaring. ${ }^{12}$

AM Saefuddin mengemukakan bahwa ulul albab adalah intelektual atau pemikir muslim yang mempunyai ketajaman analisis terhadap tanda-tanda dan proses alamiah menggunakan metode ilmiah induktif dan deduktif. Disamping itu, dia juga mampu untuk senantiasa berdzikir dalam segala kondisi sehingga dengan semua itu, ia mampu membangun dan menciptakan kemaslahatan bagi kehidupan manusia. ${ }^{13}$ Berbeda dengan AM Saefuddin, Imam Suprayogo menjelaskan bahwa Ulul Albab dengan orang yang mengutamakan zikir, fikir, dan amal saleh. Ia mempunyai keluasan ilmu, ketajaman pandangan, kecerdasan otak, kelembutan hati, semangat, dan memiliki jiwa pejuang di jalan Allah. ${ }^{14}$

Bila ditelusuri lebih lanjut term ulil albab dalam Al-Quran didapati tersebar dalam 16 ayat dalam berbagai surah yang menunjukan ciri-ciri atau karakteristik ulul albab. Berikut ayatayat yang membahas terkait ciri-ciri ulul albab tersebut: 1) Q.S. Al-Baqarah ayat 179: mampu mengambil hikmah dari konsep hukum qishas; 2) QS. Al-Baqarah 197: Memahami pentingnya bekal dalam beribadah (haji) dan sebaik-baik bekal adalah taqwa; 3) Q.S. Al-Baqarah ayat 269: menyadari dan meyakini bahwa hikmah (pemahaman yang mendalam tentang Al-Quran dan sunnah) merupakan anugerah yang besar dari Allah Swt.; 4) QS. Ali-Imran ayat 7: memahami ayat-ayat al-Quran secara mendalam; 5) QS. Ali-Imran 190-191: mampu memadukan dzikir dan pikir yang berbuah takjub akan kebesaran dan kekuasaan Allah dan bertambahnya rasa khauf akan adzab neraka; 6) Q.S. Al-Maidah ayat 100: kemampuan berpikir kritis (mampu membedakan yang baik dan buruk, walaupun yang buruk dianggap lebih menarik); 7) Q.S. Yusuf ayat 111: memahami sejarah dan dapat mengambil hikmah darinya; 8) Q.S. Ar-Ra'du

\footnotetext{
${ }^{7} \mathrm{Ng}, 1067-68$.

${ }^{8}$ A.W. Muanawwir, Kamus Al-Munawwir Arab-Indonesia. (Surabaya: Pustaka Progresif, 1997), 1247, $\mathrm{Su}$.

${ }^{9}$ Raghib Al-Asfahani, Al-Mufradat Fi Garib Al-Quran (Makatabah Nazar Musthafa Al-Baz, n.d.), 575.

${ }^{10}$ M. Quraish Shihab, Tafsir Al-Mishbah (Pesan, Kesan, Dan Keserasisan Al-Quran) Volume 2 (Jakarta: Lentera Hati, 2005), 307.

11 Shihab, 307.

12 Shihab, 308.

13 Nunuk Indarti, "Ulul Albab: Profil Intelektual Muslim Ideal Dan Relasinya Dengan Perkembangan Sains Dan Teknologi," $\quad$ Al-Makrifat 5, no. 2 (2020): http://ejournal.kopertais4.or.id/tapalkuda/index.php/makrifat/article/view/3957.

14 Indarti, 122.
} 
19-22 orang yang berintegritas dan beramal shaleh; 9) Q.S. Ibrahim 52: beraqidah yang lurus karena berpegang pada Al-Quran; 10) Q.S. As Shad 29: mampu mengambil pelajaran dari AlQuran; 11) Q.S. As-Shad ayat 43: mampu bersabar jika ditimpa cobaan dan kesulitan karena pengetahuannya bahwa buah dari kesabaran adalah keselamatan dan kebahagiaan; 12) Q.S. AzZumar ayat 9: menghidupkan malam dengan ibadah karna takut akan adzab akhirat dan berharap mendapatkan rahmat Allah; 13) Q.S. Az-Zumar ayat 18: Kritis dalam menilai suatu pemikiran dan mampu mengikuti pemikiran yang terbaik; 14) QS. Az-Zumar ayat 21: mampu mengambil pelajaran dari berbagai fenomena alam; 15) Q.S. Ghafir ayat 54: mampu mengambil pelajaran dari kisah dan syariat umat terdahulu; 16) Q.S. At-Thalaq Ayat QS. At-Thalaq 10-11: bertaqwa kepada Allah karena pengetahuannya akan setiap perbuatan yang dilakukan manusia ada balasannya (adzab bagi yg durhaka dan surga bagi yang taat).

Dawam Raharjo mencoba membuat indikator terkait sejumlah orang atau masyarakat yang dapat disebut sebagai ulul albab, antara lain: 1) mempunyai analisis yang tajam; 2) mempunyai kepekaan spiritualitas; 3) senantiasa optimis dalam menjalani kehidupan; 4) mempunyai keseimbangan jasmani-rohani; 5) mempunyai keseimbangan individual-sosial; 6) mempunyai kesimbangan dunia-akhirat; 7) bermanfaat bagi kemanusian; 8) menjadi pioneer dan pelopor dalam transformasi sosial; 9) mempunyai kemandirian dan tanggung jawab; dan 10) kokoh dan teguh dalam kepribadian. ${ }^{15}$

Sementara itu, pendapat lain diungkapkan oleh Jalaluddin Rahmat setelah mengkaji beberapa ayat terkait karakteristik Ulul Albab. Karakteristik tersebut terangkum dalam lima ciri berikut: 1) mempunyai kesungguhan dalam menuntut ilmu dan kecintaannya dalam mensyukuri nikmat Allah Swt (QS. Ali Imran: 190); 2) mempunyai kemampuan dalam memisahkan mana yang baik dan buruk, serta mampu untuk mengikuti kebaikan tersebut (QS. Al-Maidah: 100); 3) mampu bersikap kritis dalam menerima pengetahuan atau mendengar pembicaraan orang lain, serta mampu menimbang ucapan, teori, proposisi dan atau dalil yang dikemukakan orang lain tersebut (QS. Az-Zumar: 18); 4) berkomitmen untuk menyebarkan ilmunya, bertanggung jawab dalam melakukan perbaikan terhadap masyarakat, serta terpanggil hatinya untuk menjadi pelopor terciptanya kemaslahatan dalam masyarakat (QS Ibrahim: 2, Ar-Ra`d: 19-22); 5) mempunya rasa takut hanya kepada Allah Swt (QS. Al-Baqarah: 197 dan Ath-Thalaq: 10). ${ }^{16}$

Merujuk dari berbagai pendapat di atas, maka paling tidak terdapat tiga komponen utama dalam diri ulul albab, yaitu dzikir, pikir, dan amal shaleh. Hal tersebut dapat dilihat dari aspekaspek atau aktivitas utama yang dilakukan oleh ulil albab yang tidak lepas dari berpikir, berdzikir, dan berbuat kebaikan.

Berkaitan dengan dzikir, pikir, dan amal shaleh tersebut Abdul Basid memaknai dzikir dengan "ketajaman Spiritual", fikir dengan "intelektualitas yang mapan", dan amal shaleh dengan "kreatifitas dan aktivitas positif". ${ }^{17}$ Dzikir menunjukan gambaran akan keterhubungan ulul albab dengan Allah dalam setiap keadaan, pikir mengisyaratkan kemampuannya dalam memanfaatkan dan mengoptimalkan akal sehingga dapat menemukan hakikat kebenaran. Keduannya (dzikir dan fikr) saling berkaitan dan berpadu yang berbuah amal shaleh.

Ibnu Katsir menjelaskan, bahwa Ulul Albab tidak pernah terputus dari berdzikir mengingat Allah dalam setiap kondisi mereka. Hati, lisan dan jiwa mereka senantiasa mengingat Allah. Mereka juga mampu memahami hikmah yang terkandung dalam penciptaan langit dan bumi yang menunjukan kepada kebesaran Penciptanya, kekuasaan-Nya, pengetahuan-Nya, hikmah-Nya, pilihan-Nya, dan rahmat-Nya. ${ }^{18}$ Dua aktivitas utama, yakni dzikir dan pikir tersebut pada ulil albab berimplikasi pada sikap dan prilakunya dalam

\footnotetext{
${ }^{15}$ Miftahul Huda, Nur Faizin, and A. Samsul Ma`arif, "Studi Komponen Makna Frase Ulul Albâb Dalam Wacana Sufistik: Analisis Semantik" (Malang: UIN Maulana Malik Ibrahim, 2016), 19.

16 Huda, Faizin, and Ma`arif, 18.

17 Basid, "Ulul Albab Sebagai Sosok Dan Karakter Saintis Yang Paripurna," 281.

18 Ibnu Katsir, Tafsir Al-Quran Al-Adzim, 2nd ed. (Kairo: Dar Ibn Al-Jauzi, n.d.), 486.
} 
kehidupan, sehingga menjadikannya sebagai manusia yang bermanfaat dan dibutuhkan oleh umat manusia. Dengan tiga komponen utama, yaitu dzikir, pikir dan amal shaleh, menjadikan ulul albab sebagai kelompok manusia yang istimewa.

\section{Penguatan Literasi Digital Generasi Muslim dalam Kerangka Dzikir, Pikir dan Amal Shaleh}

Tantangan yang dihadapi generasi muda saat ini dinilai semakin kompleks. Hal ini disebabkan karena media digital dengan jaringan internetnya menyediakan ruang tanpa batas geografis, sehingga setiap individu dapat berinteraksi dengan siapapun, mengakses informasi darimanapun dan menyebarkan informasi kepada siapapun dengan sangat mudah. Disamping itu, problematika kehidupan, baik yang bersifat individual maupun sosial yang sejatinya dulu dalam lingkup terbatas, saat ini bertransformasi menjadi lebih luas bahkan tak terbatas. Dalam kaitan inilah perlunya peningkatan kemampuan literasi digital bagi generasi muda muslim.

Sebagaimana dipaparkan di atas, terdapat tiga aspek penting yang menjadi komponen utama ulul albab. Tiga komponen tersebut adalah dzikir, fikr, dan amal shaleh. Upaya untuk meningkatkan kualitas tiga aspek tersebut dapat dijadikan sebagai kerangka dalam upaya meningkatkan kemampuan literasi digital generasi muda muslim. Hal ini karena aspek-aspek penting tersebut dibutuhkan oleh setiap individu atau kelompok dalam menjalani kehidupanya, tidak terkecuali di era pesatnya perkembangan sains dan teknologi seperti sekarang. Harapanya melalui penguatan tiga aspek tersebut, dapat menjadikan generasi muda lebih siap dalam menghadapi berbagai tantangan di era digital ini.

Dzikir, fikr, dan amal shaleh hakikatnya merupakan tiga unsur yang terpadu dan saling terkait yang ada pada diri ulul albab. Ketiga aspek tersebut saling mempengaruhi satu sama lain. Oleh karenanya, penguatan pada satu aspek sedikit banyak dapat menguatkan aspek lainnya. Pada paparan berikut ini akan dijelaskan masing-masing aspek sebagai kerangka penguatan literasi digital bagi kaum muda muslim.

1) Menguatkan Aspek Dzikir

Sebagaimana dijelaskan pada pembahasan di atas, bahwa ulul albab adalah sekelompok manusia yang hati dan pikirannya senantiasa bertaut kepada Allah. Keterikatan transendental pada ulul albab menunjukan kedalaman aspek spiritualitas dalam dirinya. Dalam berbagai kondisi, mereka selalu mengingat Allah, baik hanya dengan hatinya saja, maupun dengan hati yang diiringi dengan lisannya yaitu dengan menyebut kalimat-kalimat thayyibah atau dengan berdoa.

Menurut Ibnu Athaillah, dzikir merupakan upaya melepaskan diri dari keadaan lalai dengan menghadirkan hati bersama Al-Haqq (Allah). ${ }^{19}$ Bagi seorang mukmin, dzikrullah adalah hal yang diperintahkan dan menunjukan amalan utama di sisi Allah. Dalam surat AlAhzab ayat 41 Allah berfirman, "wahai orang-orang yang beriman, berdzikirlah kepada Allah, dengan dzikir sebanyak-banyakannya!”. Sementara yang menunjukan dzikir termasuk ke dalam amalan utama terdapat dalam hadits Nabi sebagaimana diriwayatkan oleh Imam Tirmidzi, Rasulullah bersabda, "Maukah aku beritahukan kepada kalian mengenai amalan kalian yang terbaik, dan yang paling suci di sisi Raja (Allah) kalian, paling tinggi derajatnya, serta lebih baik bagi kalian daripada menginfakkan emas dan perak, serta lebih baik bagi kalian daripada bertemu dengan musuh kemudian kalian memenggal leher mereka dan mereka memenggal leher kalian?" Mereka berkata: ya. Beliau berkata: "berdzikir kepada Allah ta'ala."

Nabi mengajarkan banyak sekali lafadz-lafadz atau kalimat-kalimat dzikir dan doa yang dapat dijadikan acuan bagi seorang muslim dalam berdzikir dan berdoa secara lisan,

19 A.Fatoni, Integrasi Zikir Dan Pikir (Dasar Pengembangan Pendidikan Islam), ed. Andari Faqih (Forum Pemuda Aswaja, 2020), 2. 
baik dilakukan dalam serangkaian ibadah mahdhah maupun dalam beragam aktivitas lainnya. Hal ini dapat dilihat dalam berbagai kitab-kitab yang ditulis oleh para ulama, seperti kitab al-Adzkar karya Imam Nawawy, kitab Al-Ghaniyah karya Syeikh Abdul Qadir AlJailani, Shahih al-Kalimaat Thayyib li Syekh al-Islam ibn Taimiyyah dan sebagainya. ${ }^{20}$ Jika tuntunan dzikir ini diamalkan secara istiqamah disertai dengan kehadiran hati dalam kehidupan sehari-hari, maka dapat menguatkan dan memelihara seorang hamba untuk senantiasa terpaut hatinya dengan Allah.

Dzikrullah yang dilakukan secara terus menerus dapat berpengaruh pada sikap dan tindakan seorang hamba. Dengan mengingat Allah seorang individu akan terdorong untuk bersikap atau berprilaku yang disukai Allah dan menghindari bahkan membenci segala sesuatu yang dimurkai-Nya. Disamping itu, orang yang senantiasa mengingat Allah juga akan terhindar dari prilaku dan ucapan yang sia-sia. Oleh karenannya, semakin banyak seorang hamba berdzikir secara lisan yang disertai dengan kehadiran hati, maka semakin baik pula sikap dan prilakunya dalam kehidupan sehari-hari.

Dalam konteks penggunaan media digital, sikap di atas sangat dibutuhkan bagi setiap individu, terutama generasi muda saat ini yang paling intensif berinteraksi dengan media digital. Dengan berpedoman pada nilai-nilai Islam saat berselancar di dunia maya, maka seorang muslim akan terdorong untuk mengoptimalkan media digital untuk hal-hal positif dan bukan sebaliknya. Dengan demikian, hadirnya teknologi digital menjadi kian bermanfaat bagi generasi muda muslim.

Generasi muda masa kini dihadapkan pada tantangan yang tidak mudah. Berbagai media hiburan seperti beragam media social, berbagai genre film, banyak variasi game online dll banyak tersedia di media digital dan mudah didapatkan. Media hiburan tersebut bila tidak disikapi dengan baik banyak yang bersifat adiktif dan berpengaruh negatif terhadap generasi muda saat ini. Terkait media social misalnya, Anang mengungkapkan disamping terdapat pengaruh positif banyak juga didapati dampak negatif penggunaannya, yaitu: (1) menurunkan relasi dengan orang-orang disekitarnya; (2) menurunkan minat untuk pertemuan secara langsung dalam dunia nyata; (3) kecanduan internet; (4) rentan terhadap pengaruh buruk orang lain; (5) masalah privasi; (6) dan terjadinya konflik. ${ }^{21}$ Sementara terkait film, tidak jarang didapati film-film yang jauh dari nilai-nilai edukatif dan Islami, seperti konten bermuatan pornografi, kekerasan, dsb. Adapun terkait dengan game online, Jap dkk mengungkapkan hasil penelitian mereka, bahwa $10,15 \%$ remaja di Indonesia terindikasi mengalami kecanduan game online. ${ }^{22}$ Diantara permasalahan yang banyak terjadi akibat kecanduan game online antara lain: (1) kurangnya kepedulian social; (2) tidak dapat mengontrol waktu dengan baik; (3) menurunnya prestasi akademik, hubungan sosial, finansial, kesehatan; dan berbagai fungsi kehidupan lainnya. ${ }^{23}$

Perkembangan teknologi digital yang merupakan bagian tak terpisahkan dari pesatnya perkembangan sains dan teknologi merupakan salah satu saluran bagi tumbuh dan berkembangnya budaya asing dengan gaya hidup baru yang cenderung sekuler, materialistik dan hedonistik. Padangan hidup dan budaya tersebut sangat berlawan dengan pandangan Islam yang memandang manusia sebagai makhluk yang tidak hanya terdiri dari unsur jasmani, namun juga unsur rohani. Penekanan pada salah satunya atau hanya memenuhi kebutuhan aspek jasmani, akan menyebabkan kepincangan dan kekosongan jiwa. Oleh

${ }^{20}$ A.Fatoni, 5.

21 Anang Sugeng Cahyono, "Pengaruh Media Sosial Terhadap Perubahan Sosial Masyarakat Di Indonesia," Jurnal PUBLICIANA, 9(1), 140-157. 9, $\quad$ no. $1 \quad$ (2016): 154, https://journal.unita.ac.id/index.php/publiciana/article/view/79.

${ }_{22}$ Tjibeng Jap et al., "The Development of Indonesian Online Game Addiction Questionnaire," PLoS ONE 8, no. 4 (2013): 4, https://doi.org/10.1371/journal.pone.0061098.

${ }^{23}$ Eryzal Novrialdy, "Kecanduan Game Online Pada Remaja: Dampak Dan Pencegahannya," Buletin Psikologi 27, no. 2 (2019): 150, https://doi.org/10.22146/buletinpsikologi.47402. 
karenanya, penguatan aspek spiritualitas menjadi bagian yang harus selalu dikuatkan oleh seorang muslim dalam menjalani kehidupannya, baik di dunia nyata maupun dunia maya.

Meningkatkan kuantitas dan kualitas dzikrullah hakikatnya adalah membangun dan meningkatkan kesadaran seorang muslim akan visi dan misi hidupnya bahwa kehidupan dunia harusnya menjadi bekal untuk mendapatkan kebaikan Akhirat. Dengan demikian, dalam berbagai keadaan dan aktivitas, dia selalu sadar bahwa segala perbuatan yang dilakukan-sekecil apapun memiliki konsekwensi bagi kehidupannya di masa depan. Demikian pula saat bermedia digital, dia akan mengoptimalkan sarana digital untuk kebaikan dan menghindari berbagai sikap dan prilaku yang buruk, yang bertentangan dengan syariat Islam.

Untuk itu, dalam upaya membangun dan menguatkan aspek dzikir saat bermedia sosial paling tidak ada dua hal yang dapat diaktualisasikan, yaitu dengan (1) mengawalinya dengan berniat mencari ridha Allah dan; (2) berdzikir atau berdoa sebelum dan sesudah beraktivitas menggunakan media digital.

Berkaitan dengan niat, Imam Nawawi mengartikan niat dengan, "tergeraknya hati menuju apa yang dianggapnya sesuai dengan tujuan baik berupa perolehan manfaat atau pencegahan keburukan." ${ }^{24}$ Sementara Imam Suyuthi, memaknainya dengan, "keinginan yang ditujukan kepada suatu perbuatan dalam rangka memperoleh ridha Allah dan melaksanakan hukum-Nya." 25

Niat dalam suatu perbuatan memiliki nilai yang tinggi dalam Islam. Dalam sebuah hadits yang masyhur Nabi bersabda, "innamal a'malu binniyyah wa innama likullimriin ma nawa...." Sesungguhnya semua amal tergantung pada niatnya, dan setiap orang akan mendapatkan apa yang dia niatkan (HR Bukhari). Hadits tersebut menunjukan urgensi niat bagi seorang muslim. Bagi seorang muslim, setiap amal perbuatan yang baik dan bermanfaat menjadi bernilai ibadah jika dilakukan dengan keikhlasan dan mengharap ridha Allah. Hal tersebut karena niat dapat membedakan suatu perbuatan, sehingga dapat bernilai ibadah atau hanya sebatas kebiasaan. Dengan demikian, dalam kaitannya dengan beraktivitas menggunakan media digital, agar aktivitas tersebut bernilai ibadah, maka seyogyanya seorang muslim mengawalinya dengan niat yang lurus-mengharap ridha Allah.

Sementara berkaitan dengan dzikir dan doa sebenarnya hal itu merupakan komitmen bagi seorang mukmin atas keimanan yang ada pada dirinya. Doa dan dzikir sendiri berarti "suatu amalan dalam bentuk kata-kata yang diucapkan secara lisan ataupun dalam hati yang berisikan permohonan kepada Allah dengan selalu mengingat nama-Nya dan sifat-Nya." 26 Karenanya dengan melafalkan kalimat thayyibah atau dengan bermohon kepada Allah dapat membangun kesadarannya atau menjaga seorang hamba dari prilaku buruk yang bertentangan dengan syariah.

Membaca dzikir atau doa sebelum atau sesudah bermedia digital adalah untuk semakin menguatkan dan menjaga hati agar tetap terhubung secara transendental seorang hamba dengan Allah. Dengan banyak menyebut nama dan sifat-sifatNya akan membantu seorang hamba dalam menghubungkan hati dan pikirannya untuk senantiasa mengingatnya. Doa dan dzikir akan mendekatkan seorang hamba dengan Rabbnya. Dalam Q.S. Al-Baqarah ayat 152, Allah berfirman, "fadzkuruni adzkurukum, wasykuru li wala takfurun", yang artinya, "karena itu ingatlah kepada-Ku, niscaya Aku mengingatmu pula dan janganlah kamu mengingkari (nikmat)-Ku." Quraish Shihab menjelaskan penafsiran ayat tersebut, bahwa

${ }^{24}$ HM. Zainuddin, “Implementasi Niat (Intention) Dalam Kehidupan Kerja,” 2021, https://www.uinmalang.ac.id/r/131101/implementasi-niat-intention-dalam-kehidupan-kerja.html.

25 Mujiburrahman Mujiburrahman, "Fenomenologi Niat: Antara Al-Ghazali Dan Al-Sayuthi," Kanz Philosophia: A Journal for Islamic Philosophy and Mysticism 1, no. 2 (2011): 219, https://doi.org/10.20871/kpjipm.v1i2.20.

${ }^{26}$ A.Fatoni, Integrasi Zikir Dan Pikir (Dasar Pengembangan Pendidikan Islam), 8. 
Allah memerintahkan hambanya untuk mengingat-Nya dengan lidah, pikiran-hati, dan anggota badan. Lidah mensucikan dan memuji Allah, pikiran dan hatinya memperhatikan tanda-tanda kebesaran Allah, dan anggota badan melaksanakan segala perintah-perintahNya. Lebih lanjut Quraish menjelaskan, Jika semua hal tersebut dilaksanakan oleh seorang hamba, niscaya Allah akan mengingatnya pula, sehingga dia senantiasa bersama Allah dalam kondisi suka maupun duka. ${ }^{27}$ Allah juga memerintahkan hamba-Nya agar bersyukur kepadaNya dan tidak ingkar atau kufur terhadap nikmat-nikmat yang telah diberikan kepadanya yang itu dapat termanipestasikan melalui lisan, hati-pikiran dan perbuatannya. Dengan demikian, prilaku seorang hamba yang senantiasa membiasakan dirinya dengan dzikir dalam kehidupan kesehariannya baik dalam dunia nyata, maupun dunia maya akan lebih terpelihara dari prilaku-prilaku yang tercela, dan sebaliknya dia juga akan termotivasi untuk terus melakukan amal-amal shaleh sebagai bentuk rasa syukurnya kepada Allah Swt.

2) Meningkatkan Aspek Fikr

a. Menguatkan kemampuan berpikir kritis

Salah satu ciri ulul albab adalah mampu bersikap kritis. Sikap kritisnya itu ditunjukan dengan kemampuannya dalam membedakan mana yang baik dan buruk (termasuk yang halal dan yang haram, yang haq dan yang batil, yang terpuji dan yang tidak terpuji), serta mampu bersikap untuk tetap teguh memilih kebaikan-kebaikan tersebut walaupun yang buruk-buruk itu menarik hatinya (lihat Q.S. Al-Maidah ayat 100). Ciri sikap kritis lain dari ulul albab adalah kemampuannya dalam memilih yang terbaik dari beragam perkataan, pemikiran, gagasan, dan ide yang ia dengar atau yang dihadapkan kepadannya (lihat Q.S. Az-Zumar ayat 18).

Kemampuan untuk bersikap kritis merupakan kemampuan yang diperlukan generasi muda muslim saat ini dalam berinteraksi dengan media digital. Tidak dapat dipungkiri, bahwa saat ini masyarakat disuguhkan dengan beragam informasi, pengetahuan, pemikiran, pendapat, produk budaya dan lain sebagainya dalam dunia digital. Beragamnya informasi dan konten lainnya yang terdapat dalam jejaring internet tidak serta merta mengandung muatan positif dan islami, namun banyak juga mengandung muatan negatif dan jauh dari nilai-nilai Islam, seperti pemikiran-pemikiran yang bertentangan dengan syariah Islam, pornografi, berita hoax, penipuan dll. Dalam konteks literasi digital, kritisme menjadi semakin penting untuk menghalangi ketergesaan dalam melakukan penilaian terhadap kebenaran data, dan dapat juga memberi kesempatan untuk memeriksa dan menolak kebohongan informasi yang bisa saja terdapat di dalamnya. ${ }^{28}$ Dengan demikian, kemampuan berpikir kritis adalah salah satu kemampuan penting bagi generasi muda muslim yang harus terus dikuatkan dan ditingkatkan.

Diantara upaya yang perlu ditingkatkan dalam membangun kemampuan berpikir kritis di era digital yaitu dengan: (1) meningkatkan ilmu syariah dan ilmu lainnya yang dibutuhkan sebagai landasan normatif dalam pemanfaatan media digital dalam kehidupan sehari-hari; (2) memastikan kebenaran informasi, data, atau pengetahuan yang didapat dengan memperhatikan sumber informasi dan melakukan screening informasi dengan check and recheck, (3) memastikan kemanfaatan informasi atau pengetahuan yang dicari dan hendak digunakan, (4) menumbuhkan kemampuan menganalisis, membandingkan, mengevaluasi, dan memutuskan.

Bagi seorang muslim, ilmu syariah merupakan ilmu yang dibutuhkannya untuk menjalani kehidupannnya. Makna syari'ah sendiri dalam arti yang luas adalah semua

${ }_{27}$ M. Quraish Shihab, Tafsir Al-Mishbah (Pesan, Kesan, Dan Keserasian Al-Quran) Volume 1 (Jakarta: Lentera Hati, 2005), 362.

${ }^{28}$ Ahmad Sulaiman and Nandy Agustin Syakarofath, "Berpikir Kritis: Mendorong Introduksi Dan Reformulasi Konsep Dalam Psikologi Islam,” Buletin Psikologi 26, no. 2 (2018): 86, https://doi.org/10.22146/buletinpsikologi.38660. 
ajaran Islam yang diturunkan kepada Nabi Muhammad Saw sebagai panduan hidup dalam berprilaku, yang meliputi aqidah, ibadah dan akhlaq. ${ }^{29}$ Dengan kata lain, pemahaman seorang muslim terhadap agamanya, dapat dilihat sejauh dan seberapa dalam dia memahami syariah Islam. Sementara yang dimaksud dengan ilmu lainnya yang dibutuhkan oleh individu dalam menggunakan media digital yaitu terkait dengan berbagai aturan normatif yang ditetapkan negara atau yang bersifat etik yang diberlakukan dalam dunia digital.

Hal lain yang perlu diupayakan dalam membangun kemampuan berpikir kritis dalam berliterasi digital adalah dengan memastikan kebenaran informasi, data, atau pengetahuan yang didapat. Informasi, berita, atau pengetahuan yang benar secara umum dikenal juga dengan term khabar shadiq. Terkait dengan khabar itu sendiri sebagaimana diungkapkan Syaukani terbagi ke dalam tiga jenis. Pertama, khabar yang sudah pasti benar, baik yang kebenarannya bernilai pasti dan mutlak karena bersifat mutawatir dan merupakan pengetahuan a priori maupun diyakini kebenarannya setelah dilakukan penelitian, pembuktian dan pengujian secara ilmiah. Yang masuk dalam kategori yang pertama ini adalah Al-Quran dan Sunnah sebagai tingkat kebenaran tertinggi. Kedua, khabar palsu, keliru, atau dusta, yang dalam hal ini terkait segala hal yang kekeliruannya diketahui secara langsung dan pasti atau diketahui melalui proses pembuktian. Ketiga, khabar yang belum diketahui kebenaran dan kesalahannya dengan pasti. Hal ini karena belum adanya kejelasan sumber pengetahuan atau informasi. ${ }^{30}$

Informasi, berita, atau pengetahuan yang benar yang masuk dalam kategori khabar shadiq sebagaimana disebutkan di atas, selain yang bersumber dari Al-Quran dan Sunnah sebagai otoritas kebenaran mutlak dapat juga bersumber dari kesepakatan para ulama ${ }^{31}$ atau kesepakatan umum para ahli atau ilmuan ${ }^{32}$ dan khabar dari orang terpercaya secara umum. ${ }^{33}$ Hanya saja untuk kategori ini otoritasnya tidak sampai pada posisi yang bersifat mutlak.

Dengan demikian, sumber informasi dan pengetahuan menjadi hal yang tidak terpisahkan dengan informasi atau pengetahuaan itu sendiri. Al-Qur'an sendiri memberikan petunjuk, agar seseorang mencari informasi atau pengetahuan yang tidak diketahuinya yaitu dengan bertanya kepada orang yang terpercaya dan otoritatif. Dalam Q.S. An-Nahl ayat 43 disebutkan, "Dan Kami tidak mengutus sebelum Engkau wahai Muhammad, melainkan seorang laki-laki yang Kami beri wahyu kepada mereka, maka bertanyalah kepada orang yang mempunyai pengetahuan jika kamu tidak mengetahui." Ayat tersebut menegaskan pentingnya untuk bertanya dan mencari informasi kepada sumber otoritatif dan dapat dipercaya.

Disamping sumber informasi atau pengetahuan, hal lain yang penting untuk memastikan kebenaran informasi adalah dengan melakukan check and recheck. Upaya ini dilakukan sebagai bentuk filterisasi informasi atau pengetahuan yang didapatkan dan sikap kehati-hatian dalam menerima dan menyebarkan berbagai informasi di tengah derasnya arus informasi yang tersedia di media digital. Melalui mekanisme demikian harapannya dapat mengurangi bahkan menghilangkan resiko yang dapat menyebabkan kerugian, baik bagi diri sendiri, maupun orang lain di kemudian hari. Dalam Q.S. Al-

29 Djaenab, “Syari'ah : (Konsep Dasar, Urgensi Dan Tujuannya)," Ash-Shahabah: Jurnal Pendidikan Dan Studi Islam 4, no. 1 (2018): 83, https://journal-uim-makassar.ac.id/index.php/ASH/article/view/214.

30 Mohammad Syam'un Salim, "Khabar Sadiq; Sebuah Metode Transmisi Ilmu Pengetahuan Dalam

Islam,” Kalimah 12, no. 1 (2014): 99, https://doi.org/10.21111/klm.v12i1.220.

31 Budi Handrianto, "Sains Islam: Makna Filosofis Dan Model Islamisasi," in Islamic Science (Paradigma, Fakta Dan Agenda) (Jakarta: Insists, n.d.), 64.

32 Wan Mohd Nor Wan Daud, "Epiestemologi Islam Dan Tantangan Pemikiran Umat," Islamia (Jakarta: Khairul Bayan \& Insists, 2005), 72.

33 Budi Handrianto, “Sains Islam: Makna Filosofis Dan Model Islamisasi,” 64. 
Hujurat, Allah berfirman yang artinya "Wahai orang-orang yang beriman, jika seorang fasik datang kepadamu membawa berita penting, maka telitilah kebenarannya agar kamu tidak mencelakakan suatu kaum karena ketidaktahuan(-mu) yang berakibat kamu menyesali perbuatanmu itu." Seorang muslim juga diajarkan untuk tidak menyebarkan begitu saja setiap kabar atau berita yang didengarnya atau didapatkannya, karena tidak menutup kemungkinan, dari sekian banyak informasi yang didengarnya atau didapatkanya terdapat informasi yang menunjukan kabar dusta. Abu Hurairah meriwayatkan bahwa Nabi Saw. bersabda, "Cukuplah seseorang (dianggap) berdusta jika ia menceritakan semua yang ia dengar." (HR. Muslim)

Dalam menyikapi konten atau informasi di media digital sudah selayaknya bagi seorang muslim untuk bersikap cermat, teliti dan berhati-hati. Dalam Fatwa Majelis Ulama Indonesia Nomor 24 tahun 2017, ada beberapa hal yang patut untuk diperhatikan sehingga dapat menjadi pertimbangan dalam menyikapi konten atau informasi di media sosial, diantaranya: (1) konten/informasi yang berasal dari media sosial memiliki kemungkinan benar dan salah; (2) konten/informasi yang baik belum tentu benar; (3) konten/informasi yang benar belum tentu bermanfaat; (4) konten/informasi yang bermanfaat belum tentu cocok untuk disampaikan ke ranah publik; (5) tidak semua konten/informasi yang benar itu boleh dan pantas disebar ke ranah publik. ${ }^{34}$ Kriteria tersebut patut diperhatikan dan dipertimbangkan sebagai langkah kehati-hatian dalam menyikapi berbagai hal yang didapatkan melalui media digital.

Hal ketiga terkait membangun sikap kritis dalam berliterasi digital yaitu dengan memastikan kemanfaatan informasi atau pengetahuan yang hendak dicari dan didapatkan. Seorang muslim dituntut untuk menjadikan segala yang diperbuat dan dilakukannya bernilai dan bermakna. Kebermaknaan dalam suatu aktivitas dapat juga difahami dengan kebermanfaat aktivitas tersebut. Bahkan kualitas individu dapat dilihat juga dari aspek kemanfaatannya. Dalam menggunakan media digital, aspek kemanfaatan informasi dan pengetahuan menjadi bagian yang seharusnya menjadi perhatian seorang muslim. Rasulullah mengajarkan kepada umatnya untuk meninggalkan hal-hal yang tidak bermanfaat baginya. Sebagaimana diriwayatkan oleh Imam Tirmidzi, Nabi bersabda, "Di antara kebaikan Islam seseorang adalah meninggalkan hal yang tidak bermanfaat baginya."

Hal terakhir yang perlu ditumbuhkan untuk membangun sikap kritis adalah dengan menumbuhkan kemampuan menganalisis, membandingkan, mengevaluasi dan memutuskan. Empat kemampuan tersebut terkandung dalam surat Q.S. Al-Maidah ayat 100 dan Q.S. Az-Zumar ayat 18 sebagaimana telah disebutkan di atas. Untuk mampu membedakan mana yang baik dan buruk dibutuhkan kemampuan analisis dan perbandingan. Sementara untuk kemampuan memilih yang terbaik, lalu memutuskan untuk mengamalkan pilihannya tersebut, disamping dua kemampuan sebelumnya yakni analisis dan perbandingan, dibutuhkan pula kemampuan mengevaluasi dan memutuskan. Dalam upaya meningkatkan keempat kemampuan tersebut diperlukan kesungguhan dan upaya terus menerus dalam meningkatkan dan mengasahah daya pikir. Al-Quran sendiri terus mendorong agar setiap individu meningkatkan kemampuan berpikirnya dengan berbagai term yang beragam seperti membaca (iqra'), memandang dengan seksama (nadzar), berpikir (tafakkur), merenungkan (tadabbur), mendalami pemahaman (tafaqquh), mengambil pelajaran (I'tibar), mengajukan pertanyaan (hal yastawi), berpikir atau menggunakan akal (ta'qilun) dan sebagainnya.

34 MUI, "FATWA MAJELIS ULAMA INDONESIA Nomor : 24 Tahun 2017 Tentang Hukum Dan Pedoman Bermuamalah Melalui Media Sosial” (Jakarta-Indonesia, 2017), 13. 
b. Menggunakan media digital untuk meningkatkan wawasan dan keterampilan

Hadirnya media digital sejatinya semakin memudahkan generasi muda dalam mengakses informasi dan ilmu pengetahuan sehingga dapat meningkatkan ilmu, wawasan dan keterampilannya. Di era ini, untuk mengakses atau mendapatkan informasi, seseorang hanya perlu menggunakan gadget sederhana dan akses internet yang stabil tanpa memerlukan peralatan yang banyak. Hal tersebut juga dapat dilakukan di mana saja dan kapan saja selama masih mendapatkan sinyal internet. Berbagai kendala terkait ruang, waktu dan tempat dalam mendapatkan informasi atau pengetahuan dapat diperkecil dengan hadirnya media digital.

Zaenuddin mengungkapkan bahwa ada lima manfaat yang didapatkan melalui internet, antara lain: (1) komunikasi interaktif, yang dalam hal ini dapat memfasilitasi komunikasi antar personal atau kelompok tanpa dibatasi ruang dan waktu, seperti media, video conferences, internet relays, chat dan internet phone. (2) Akses terhadap pakar, yang dalam konteks ini seseorang dapat belajar dengan mudah kepada para pakar sesuai bidang ilmu atau keahliannya;. (3) kemudahan mengakses perpustakaan yang saat ini tidak lagi terbatas pada buku dan jurnal cetak, namun dapat diakses secara digital yang banyak tersedia di berbagai perguruan tinggi; (4) sebagai alat bantu dalam pengembangan pengetahuan dan penelitian; dan (5) dapat membangun kolaborasi dengan lebih mudah. ${ }^{35}$ Disamping beberapa hal tersebut, di era pandemi ini inovasi teknologi dalam berbagai bidang termasuk pendidikan terus meningkat pesat.

Dalam dunia pendidikan sendiri,

Oleh karenanya, media digital sangat memungkinkan untuk dijadikan sumber ilmu, informasi, dan mengasah keterampilan, serta media yang potensial dalam meningkatkan sumber daya insani yang handal. Tidak sedikit juga karya ulama, cendikiawan muslim, ilmuan, dan berbagai sumber otoritatif lainnya yang dapat diambil dan dimanfaatkan untuk meningkatkan wawasan, pengetahuan dan keterampilan. Hanya saja sebagaimana yang dijelaskan di atas, generasi muda muslim perlu kritis dan selektif dalam mengambil berbagai hal dalam dunia digital. Hal tersebut agar tidak keliru dan merugikan diri sendiri atau orang lain dikemudian hari karena tidak tepat dalam mengambil informasi atau pengetahuan.

3) Meningkatkan Kualitas dan Kuantitas Amal Shaleh

Amal shaleh sejatinya tidak terlepas dari dua kemampuan di atas, yakni daya pikir dan dzikir. Semakin baik kualitas dzikir dan pikirnya, maka hal tersebut akan mendorong kepada kualitas amalnya. Keterpautan seorang muslim dengan Rabbnya yang ditunjukan dengan niatnya untuk mencari ridha Allah dalam melakukan aktivitas disertai dengan ilmu yang dimilikinya dapat semakin menjadikan amalnya bermakna dan bermanfaat, baik bagi diri sendiri maupun bagi yang lain.

Teknologi digital hakikatnya adalah sarana atau instrumen yang sejatinya dapat dioptimalkan untuk berbagai kemanfaatan umat manusia. Termasuk dalam kaitan ini untuk melakukan berbagai kebaikan yang diajarkan Islam.

Islam mengajarkan umatnya untuk mengamalkan dan mengajarkan ilmu yang dimilikinya agar dapat bermanfaat tidak hanya bagi orang lain tapi juga hakikatnya bagi dirinya sendiri. Nabi Muhammad bersabda, "Jika seseorang meninggal dunia, maka terputuslah amalannya kecuali tiga perkara, yaitu: sedekah jariyah, ilmu yang bermanfaat, atau do'a anak yang sholeh" (HR. Muslim no. 1631). Media digital dapat menjadi sarana untuk menyebarkan ilmu atau informasi yang bermanfaat tersebut. Kemanfaatan ilmu

35 Zaslina Zainuddin and Universitas Sumatera Utara, “Pola Pemanfaatan Internet Oleh Mahasiswa Program Magister Ilmu Hukum Program Pascasarjana Universitas Sumatera Utara Zaslina Zainuddin Departemen Studi Perpustakaan Dan Informasi," Jurnal Studi Perpustakaan Dan Informasi 2, no. 1 (2006): 39. 
sebagaimana dijelaskan pada hadits tersebut akan semakin mudah dan luas jangkauannya melalui teknologi digital. Apalagi masyarakat Indonesia sendiri semakin banyak yang melek digital dan perkembangannnya sangat signifikan. Untuk tahun 2019-2020 sebagaimana dijelaskan di atas, masyarakat yang dapat mengakses internet mencapai 73,7 \% dari total polulasi Indonesia. Dengan demikian, media digital menjadi media yang sangat potensial untuk dijadikan sebagai sarana dakwah dalam menyebarkan informasi atau ilmu yang bermanfaat.

Cakupan ilmu pengetahuan dan informasi yang dimaksud di atas tidak terbatas pada ilmu aqidah, fiqih dan akhlaq saja, tapi mencakup berbagai bidang ilmu yang dibutuhkan oleh umat, seperti bidang kesehatan, hukum, ekonomi, pendidikan, psikologi, teknologi informasi dll. Beragam bidang ilmu dan informasi yang positif dan edukatif tersebut sangat dibutuhkan bagi umat, terutama untuk meningkatkan literasi umat saat ini. Hal tersebut karena masyarakat modern saat ini tidak bisa lepas dari teknologi digital sehingga penyediaan beragam informasi yang positif dan bermanfaat perlu terus ditingkatkan baik dari aspek kualitas informasinya maupun kuantitasnya.

Media digital dapat juga digunakan seorang muslim untuk menyeru manusia kepada kebaikan dan mencegah terjadinya berbagai keburukan. Amar ma'ruf nahi munkar adalah tugas bersama yang harus terus ditingkatkan untuk membangun bangsa yang beradab. Bila dalam dunia digital terdapat sisi negatif yang dapat berdampak negatif bagi umat maupun mansyarakat secara umum, maka peran umat adalah menguatkan dan meningkatkan sisi lainnya yaitu sisi positif dari media digital sehingga dapat berdampak positif bagi umat secara khusus dan masyarakat secara umum. Berbagai problem sosial dan pendidikan yang terjadi di dunia maya perlu direspon dengan tepat dan cepat, seperti kasus prostitusi online yang semakin marak, ${ }^{36}$ penipuan dalam jual-beli online, ${ }^{37}$ pelecehan agama, kecanduan game online yang dialami banyak generasi muda saat ini, peredaran narkoba dll. Kominfo sendiri menyampaikan, bahwa pada tahun 2019 kominfo menerima aduan terkait dengan konten negatif yang terdapat di sosial media sebanyak 500 ribu aduan. ${ }^{38}$ Sementara itu, di tahun 2021 per-februari kominfo menyebutkan laporan konten negatif di media sosial sebanyak 1.347.179 laporan, konten yang terbanyak yang diadukan adalah konten pornografi yaitu sebanyak 1.073.886 temuan dan konten perjudian sebanyak 251.631 temuan. ${ }^{39}$ Beragam kasus tersebut, disamping perlu atensi dan tindakan nyata dari pihak berwenang, tapi perlu juga kesadaran dan peran umat Islam dan masyarakat secara umum agar dapat mengurangi atau bahkan menghilangkan berbagai sisi negatif yang terdapat pada media digital tersebut.

Di tengah pesatnya perkembangan teknologi digital, umat Islam perlu berperan aktif memberikan sumbangsih dalam memproduksi berbagai konten atau media positif, edukatif dan Islami berbasis teknologi digital. Semangat berlomba-lomba dalam kebaikan (fastabiqul khairat) harus dibangun dan terus ditingkatkan. Berbagai macam inovasi dan kreativitas dalam pembuatan media atau konten-konten yang dibutuhkan umat perlu menjadi prioritas umat Islam. Membuat konten-konten dakwah dalam berbagai bentuk, dalam bentuk tulisan, audio, visual, atau audio visual atau media berbentuk aplikasi atau software. Hal itu perlu dilakukan untuk kemudahan dan efektifitas umat dalam mendapatkan ilmu dan

36 Melinda Arsanti, “Penggunaan Media Sosial Sebagai Sarana Prostitusi Online,” E-Journal Ilmu Komunikasi 5961, no. 3 (2017): 50-62, ejournal.ilkom.fisip-unmul.ac.id.

37 Muhammad Kamran and Maskun Maskun, "Penipuan Dalam Jual Beli Online: Perspektif Hukum Telematika," Balobe Law Journal 1, no. 1 (2021): 43-44, https://doi.org/10.47268/balobe.v1i1.501.

38 Wibowo Adi, "Penggunaan Media Sosial Sebagai Trend Media Dakwah Pendidikan Islam Di Era Digital," Jurnal Islam Nusantara 03, no. 02 (2019): 342.

39 Agus Yulianto, "Kominfo: Ada 1,3 Juta Konten Negatif Laporan Warganet," Republika.Co.Id, December 23, 2021, https://www.republika.co.id/berita/qrlbxi396/kominfo-ada-13-juta-konten-negatiflaporan-warganet. 
informasi yang baik dan benar. Selain itu, hal tersebut juga dapat menjadi penyeimbang bahkan mengkounter berbagai konten negatif yang merusak kehidupan masyarakat luas.

Sebagai instrumen, media digital juga sejatinya dapat digunakan untuk membangun dan menguatkan silaturrahim dan ukhuwwah Islamiyyah. Melalui media digital, masyarakat saat ini dimudahkan untuk berkomunikasi tanpa perlu berada dalam satu tempat. Seorang dapat berkomunikasi dengan keluarga, kerabat, teman, kolega dll walaupun tidak hadir secara langsung di tempat yang sama. Namun demikian, hal tersebut tentu bukan berarti bahwa masyarakat saat ini tidak membutuhkan pertemuan. Kunjungan langsung tetap dibutuhkan, hanya saja bila tidak sempat berkunjung karena waktu yang tidak memungkinkan, maka teknologi digital menjadi alternatif yang dapat digunakan untuk menjaga hubungan baik tersebut. Disamping itu, media sosial yang banyak digunakan oleh masyarakat, dapat juga digunakan sebagai sarana membangun komunitas ilmu dan dakwah yang berdampak tidak hanya meningkatkan ilmu, wawasan, dan kemampuan anggotanya, tapi dapat juga berpengaruh untuk menguatkan hubungan antar anggota.

Hal lain yang perlu juga untuk diperhatikan oleh generasi muda muslim saat ini adalah akhlak dalam bermedia sosial. Dalam bermedia sosial, paling tidak ada tiga aktivitas utama yang sering dilakukan oleh masyarakat secara umum, yaitu: (1) membuat, memposting atau menyebarkan konten; (2) mengomentari postingan; dan (3) melakukan chating.

Dalam hal membuat konten, penting untuk diperhatinkan bahwa (1) konten yang dibuat adalah konten yang benar, positif dan bermanfaat; (2) tidak berisi konten fahisyah atau munkar, seperti pornografi, pornoaksi, umpatan, hoax, namimah, kekerasan yang dilarang, dan provokatif; (3) tidak bersifat pribadi yang tidak layak untuk disebarluaskan, seperti keluh-kesah, aib keluarga, kerabat atau teman dan; (4) tidak melanggar hukum. Dalam hal memposting atau menyebarkan informasi, yang perlu diperhatikan selain empat hal tersebut yaitu bahwa jika informasi hendak disebarkan secara bebas, maka perlu memperhatikan kesesuaian dan kelayakannya untuk dikonsumsi oleh semua kalangan, namun jika hendak disebarkan untuk kalangan tertentu, maka perlu menyesuaikan dengan sasarannya. Hal lainnya, yang juga perlu diperhatikan adalah kesesuaian waktu, tempat dan konteks informasi tersebut.

Sementara dalam hal mengomentari postingan, yang perlu diperhatikan adalah (1) menggunakan bahasa yang santun dan ramah; (2) tidak menggunjing, memfitnah dan menggunakan kalimat yang menunjukan ujaran kebencian; (3) bila konten postingan positif dan bermanfaat dapat juga diberikan apresiasi, misalnya dengan me-like dsb. Adapun terkait dengan chatting yang perlu diperhatikan yaitu: (1) menggunakan bahasa yang ma'ruf; (2) tidak menggibah, memfitnah, mem-bully $d s b$; serta (3) tidak chatting yang berpotensi menimbulkan fitnah, seperti chatting belebihan dengan yang bukan mahram.

Umat Islam diajarkan untuk menjaga akhlaq dalam kehidupan sosialnya. Demikian juga dalam bermedia sosial, penerapan akhlaq seharusnya menjadi hal utama yang harus diperhatikan seorang muslim. Dalam kaitan ini dalam Q.S. Ali Imran ayat 112, Allah berfirman yang artinya, "Mereka akan dilanda kehinaan kecuali jika menjaga hubungannya dengan Tuhan dan hubungannya dengan sesama..." Nabi Muhammad Saw sendiri diutus adalah untuk menyempurnakan akhlaq. Dengan demikian, bagi seorang muslim penerapan akhlaq dalam kehidupan nyata maupun maya merupakan sebuah keniscayaan yang harus dijaga dan terus ditingkatkan. Akhlak yang baik tidak hanya mendatangkan ketentraman bagi individu tapi juga mampu menciptakan ketentraman dan kemaslahatan bagi masyarakat secara umum. 


\section{Simpulan}

Generasi muda saat ini dihadapkan pada tantangan yang semakin kompleks. Media digital dengan jaringan internetnya menyediakan ruang tanpa batas geografis yang memungkinkan setiap individu untuk berinteraksi dengan siapapun serta dapat mengakses dan menyebarkan informasi apapun dengan sangat mudah. Disamping itu, problematika kehidupan, baik yang bersifat individual maupun sosial yang sejatinya dulu dalam lingkup terbatas, saat ini bertransformasi menjadi lebih luas bahkan tak terbatas. Dalam kaitan inilah perlunya peningkatan kemampuan literasi digital bagi generasi muda muslim.

Literasi digital dalam kerangka konsep ulil albab merupakan upaya peningkatan literasi digital melalui penguatan dan peningkatan tiga komponen utama ulul albab yaitu dzikir, pikir dan amal shaleh. Meningkatkan dzikrullah hakikatnya adalah membangun dan meningkatkan kesadaran seorang muslim akan visi dan misi hidupnya bahwa kehidupan dunia harusnya menjadi bekal untuk mendapatkan kebaikan Akhirat. Dalam berbagai keadaan dan aktivitas, dia selalu sadar bahwa segala perbuatan yang dilakukan-sekecil apapun memiliki konsekwensi bagi kehidupannya di masa depan. Demikian pula saat bermedia digital, dia akan mengoptimalkan sarana digital untuk kebaikan dan menghindari berbagai sikap dan prilaku yang buruk, yang bertentangan dengan syariat Islam. Sementara untuk penguatan dan peningkatan dari aspek pikir yaitu dengan menguatkan dan meningkatkan aspek berpikir kritis, yang dapat dilakukan dengan: (1) meningkatkan ilmu syariah dan ilmu lainnya yang dibutuhkan sebagai landasan normatif dalam pemanfaatan media digital dalam kehidupan sehari-hari; (2) memastikan kebenaran informasi, data, atau pengetahuan yang didapat dengan memperhatikan sumber informasi dan melakukan screening informasi dengan check and recheck, (3) memastikan kemanfaatan informasi atau pengetahuan yang dicari dan hendak digunakan, (4) menumbuhkan kemampuan menganalisis, membandingkan, mengevaluasi, dan memutuskan. Hal lain yang juga dapat dilakukan untuk meningkatkan aspek pikir adalah dengan menggunakan media digital sebagai sarana peningkatan wawasan dan keterampilan generasi muda. Adapun terkait amal shaleh, sejatinya tidak terlepas dari aspek dzikir dan pikir. Semakin baik kualitas dzikir dan pikirnya, maka hal tersebut akan mendorong kepada kualitas amalnya juga. Media digital dapat menjadi sarana dalam melakukan berbagai kebaikan yang berlandaskan syariat, seperti menebarkan ilmu yang bermanfaat, menyeru kepada kebaikan dan mencegah kemunkaran (amar-makruf nahi munkar), memprodukasi berbagai media atau konten digital yang positif-edukatif dan Islami, menguatkan silaturrahim dan ukhuwwah Islamiyyah, serta menjaga akhlak dalam bermedia sosial. 


\section{DAFTAR PUSTAKA}

A.Fatoni. Integrasi Zikir Dan Pikir (Dasar Pengembangan Pendidikan Islam). Edited by Andari Faqih. Forum Pemuda Aswaja, 2020.

Adi, Wibowo. "Penggunaan Media Sosial Sebagai Trend Media Dakwah Pendidikan Islam Di Era Digital.” Jurnal Islam Nusantara 03, no. 02 (2019): 339-56.

Arsanti, Melinda. "Penggunaan Media Sosial Sebagai Sarana Prostitusi Online." E-Journal Ilmu Komunikasi 5961, no. 3 (2017): 50-62. ejournal.ilkom.fisip-unmul.ac.id.

Asosiasi Penyelenggara Jasa Internet Indonesia. "Laporan Survei Internet APJII 2019 - 2020 (Q2)." Asosiasi Penyelenggara Jasa Internet Indonesia. Vol. 2020, 2020. https://apjii.or.id/survei.

Basid, Abdul. "Ulul Albab Sebagai Sosok Dan Karakter Saintis Yang Paripurna." In PROSIDING : Seminar Nasional Fisika Dan Pendidikan Fisika, Vol 1, No:281-91, 2012.

Budi Handrianto. "Sains Islam: Makna Filosofis Dan Model Islamisasi." In Islamic Science (Paradigma, Fakta Dan Agenda), 56-81. Jakarta: Insists, n.d.

Cahyono, Anang Sugeng. "Pengaruh Media Sosial Terhadap Perubahan Sosial Masyarakat Di Indonesia." Jurnal PUBLICIANA, 9(1), 140-157. 9, no. 1 (2016): 140-57. https://journal.unita.ac.id/index.php/publiciana/article/view/79.

Djaenab. "Syari'ah: (Konsep Dasar, Urgensi Dan Tujuannya)." Ash-Shahabah: Jurnal Pendidikan Dan Studi Islam 4, no. 1 (2018): 78-84. https://journal-uimmakassar.ac.id/index.php/ASH/article/view/214.

HM. Zainuddin. "Implementasi Niat (Intention) Dalam Kehidupan Kerja," 2021. https://www.uin-malang.ac.id/r/131101/implementasi-niat-intention-dalam-kehidupankerja.html.

Huda, Miftahul, Nur Faizin, and A. Samsul Ma arif. "Studi Komponen Makna Frase Ulul Albâb Dalam Wacana Sufistik: Analisis Semantik.” Malang: UIN Maulana Malik Ibrahim, 2016.

Indarti, Nunuk. "Ulul Albab: Profil Intelektual Muslim Ideal Dan Relasinya Dengan Perkembangan Sains Dan Teknologi." Al-Makrifat 5, no. 2 (2020): 115-41. http://ejournal.kopertais4.or.id/tapalkuda/index.php/makrifat/article/view/3957.

Jap, Tjibeng, Sri Tiatri, Edo Sebastian Jaya, and Mekar Sari Suteja. "The Development of Indonesian Online Game Addiction Questionnaire.” PLOS ONE 8, no. 4 (2013): 4-8. https://doi.org/10.1371/journal.pone.0061098.

Kamran, Muhammad, and Maskun Maskun. "Penipuan Dalam Jual Beli Online: Perspektif Hukum Telematika." Balobe Law Journal 1, no. 1 (2021): 41-56. https://doi.org/10.47268/balobe.v1i1.501.

Katsir, Ibnu. Tafsir Al-Quran Al-Adzim. 2nd ed. Kairo: Dar Ibn Al-Jauzi, n.d.

Lankshear, Colin, and Michele Knobel. "Digital Literacy and Digital Literacies: Policy, Pedagogy and Research Considerations for Education." Nordic Journal of Digital Literacy 
2015, no. 4 (2015): 8-20. https://doi.org/10.18261/issn1891-943x-2015jubileumsnummer-02.

Muanawwir, A.W. Kamus Al-Munawwir Arab-Indonesia. Surabaya: Pustaka Progresif, 1997. $\mathrm{Su}$.

MUI. "FATWA MAJELIS ULAMA INDONESIA Nomor : 24 Tahun 2017 Tentang Hukum Dan Pedoman Bermuamalah Melalui Media Sosial.” Jakarta-Indonesia, 2017.

Mujiburrahman, Mujiburrahman. "Fenomenologi Niat: Antara Al-Ghazali Dan Al-Sayuthi." Kanz Philosophia: A Journal for Islamic Philosophy and Mysticism 1, no. 2 (2011): 215. https://doi.org/10.20871/kpjipm.v1i2.20.

Ng, Wan. "Can We Teach Digital Natives Digital Literacy?" Computers and Education 59, no. 3 (2012): 1065-78. https://doi.org/10.1016/j.compedu.2012.04.016.

Novrialdy, Eryzal. "Kecanduan Game Online Pada Remaja: Dampak Dan Pencegahannya." $\begin{array}{llllll}\text { Buletin Psikologi } & 27, & \text { no. } & 2 & \text { (2019): } & 148-58 .\end{array}$ https://doi.org/10.22146/buletinpsikologi.47402.

Raghib Al-Asfahani. Al-Mufradat Fi Garib Al-Quran. Makatabah Nazar Musthafa Al-Baz, n.d.

Rizaty, Monavia Ayu. "Masyarakat RI Paling Banyak Gunakan Internet Untuk Berkomunikasi," 2021. https://databoks.katadata.co.id/datapublish/2021/07/29/masyarakat-ri-paling-banyakgunakan-internet-untuk-berkomunikasi.

Salim, Mohammad Syam'un. “Khabar Sadiq; Sebuah Metode Transmisi Ilmu Pengetahuan Dalam Islam.” Kalimah 12, no. 1 (2014): 91. https://doi.org/10.21111/klm.v12i1.220.

Shihab, M. Quraish. Tafsir Al-Mishbah (Pesan, Kesan, Dan Keserasian Al-Quran) Volume 1. Jakarta: Lentera Hati, 2005.

Tafsir Al-Mishbah (Pesan, Kesan, Dan Keserasisan Al-Quran) Volume 2. Jakarta: Lentera Hati, 2005.

Sulaiman, Ahmad, and Nandy Agustin Syakarofath. "Berpikir Kritis: Mendorong Introduksi Dan Reformulasi Konsep Dalam Psikologi Islam.” Buletin Psikologi 26, no. 2 (2018): 86. https://doi.org/10.22146/buletinpsikologi.38660.

Syaripudin, Acep, Deni Ahmad, Dewi Widya Ningrum, Indriyanto Banyumurti, and Merry Magdalena. Kerangka Literasi Digital Indonesia. www.literasidigital.id, n.d.

Wan Daud, Wan Mohd Nor. "Epiestemologi Islam Dan Tantangan Pemikiran Umat." Islamia. Jakarta: Khairul Bayan \& Insists, 2005.

Yulianto, Agus. "Kominfo: Ada 1,3 Juta Konten Negatif Laporan Warganet." Republika.Co.Id, December 23, 2021. https://www.republika.co.id/berita/qrlbxi396/kominfo-ada-13-jutakonten-negatif-laporan-warganet. 
Zainuddin, Zaslina, and Universitas Sumatera Utara. "Pola Pemanfaatan Internet Oleh Mahasiswa Program Magister Ilmu Hukum Program Pascasarjana Universitas Sumatera Utara Zaslina Zainuddin Departemen Studi Perpustakaan Dan Informasi." Jurnal Studi Perpustakaan Dan Informasi 2, no. 1 (2006): 37-48. 